\title{
A Case Study on Action Research: Barri Gòtic Barcelona
}

\author{
Xavi Camino*, Albert Fuster \\ Department of Social Sciences, ELISAVA Escola Superior en Disseny - UPF, Barcelona, Spain \\ *Corresponding author: xcamino@elisava.net \\ Received February 11, 2015; Revised March 10, 2015; Accepted March 19, 2015
}

\begin{abstract}
The Design Degree program at Elisava Escuela Superior de Diseño e Ingeniería de Barcelona includes tools and mechanisms to focus students on the users, the social context and communication. The idea behind this is that greater density should be sought in the projects and a fabric of relationships should be generated in a social and geographical environment ranging from the most local to the most global. As part of its "Products, context and user" subject, Elisava planned action research during the 2010-11 academic year between a group of graphic design students and the members of the 'Asociación de vecinos del barri Gòtic' (AVVBG or Gothic Quarter Community Association), the Gothic Quarter being the district of Barcelona where the School is situated. As the AVVBG has few members, it considered the need to develop new communicative strategies. The teachers provided the students with the traditional social science methods (documentary sources, participant observation, in-depth interviews) with two goals: the first, that they might become deeply aware of the district's social reality, its relationship with the rest of the city and the true needs of the AVVBG (diagnosis); and the second, to establish bonds with the members of the AVVBG that would lead to starting spaces for reflection, joint creation and joint participation in designing the association's new communication strategies. The changes between the students' first proposal made with the typical conventional project methodology, and the following, after the action research and the users, students and tutors' reply, give a good account of the values and challenges of this methodology and enable design discipline self reflection.
\end{abstract}

Keywords: Research-action, critical social science, Barcelona

Cite This Article: Xavi Camino, and Albert Fuster, “A Case Study on Action Research: Barri Gòtic Barcelona.” American Journal of Educational Research, vol. 3, no. 4 (2015): 412-417. doi: 10.12691/education3-4-5.

\section{Introduction}

In ELISAVA, students experience processes of awareness-raising and reflection on their own perspective as designers in a certain situation based on a commission. At the same time, as teacher-tutors we reflect and research on this educational process with the students themselves. However, time availability, the nature of the project and the involvement of the students and teachers rarely allow processes to develop beyond the initial premises and to expand the students, teachers and users' knowledge and experience.

Here we start to reflect on education in the design area. We therefore start with a specific experience carried out by third-year ELISAVA design undergraduates. During this experience, we decided to explore the possibilities of critical theory [1] and action research [2], in a designfocused educational process. Firstly, we will study what a design must be like when it is focused from critical theory. Then, to investigate a new educational model for design, we will discover, explain and assess the specific experience from this critical focus. Finally, we will give conclusions to open up new lines of work for the future of design teaching.

\section{Critical Theory and Design Projects}

Historically, design school educational methodology has always had a general tendency to contemplate practical problems as theoretical matters. This dominant tendency is based on the positivist thought inherited from natural sciences. This has certain implications and consequences on design projects. According to J. Habermas (1982), positivism is characterised above all by its technical interest. The knowledge of any discipline guided by positivist thought therefore focuses above all on the accumulation of technical knowledge which, if suitably applied, solves problems. When applied to the traditional training process seen in many design schools, it consists of students acquiring knowledge to give them technical control over the problems that they will face in their future profession.

This technical interest in the design discipline and in many other disciplines and sciences is essential and accounts for a large part of the developments in the history of design. However, this is not the only type of legitimate knowledge. Under the influence of the hermeneutic tradition of social sciences in line with the ideas of $\mathrm{J}$. Habermas (1982), the design field has also incorporated a practical interest capable of producing knowledge 
following the interpretative understanding of the phenomena or problems approached. This interest applies to all design projects that, before proposing technical knowledge, have focused on understanding the problem they are intended to face, recognising the interaction there is between the product, the context and the users, and reflecting on it.

Transferred to the design project, this focus considers the need to make research that helps the problem to be understood before dealing with it from a technical point of view. Therefore, the results of research under this perspective can be taken as practical knowledge which completes and directs technical knowledge. The educational programs of the second period of the Bauhaus and above all the Ulm School project already included the concern for society and the deep knowledge of its present or future needs through the social sciences (Margolin 1991). However, according to critical theory, the practical knowledge this focus produces in social sciences is somewhat limited if we consider the social, cultural and political conditions that have configured the researcher's view (understanding). In other words, as J. Habermas (Habermas 1982) argues, the different types of knowledge are configured by the particular human interest they serve. Therefore, the knowledge depends on the subject's social position, their discourse and interest within a certain field of which they form a part (design, engineering, sport, etc.). According to critical theory, these conditioners must be revealed by self-reflection throughout the investigation to emancipate knowledge from such conditions. In design, this is akin to saying that designers must not base their theory only on the interpretations they make of the problems their trade poses for them. A self-reflection process is worthwhile to free oneself of these constraints on one's viewpoint. In social sciences, recognition of the subjectivity promoted by hermeneutics or the phenomenology during the investigation processes is an open path towards this reflexive focus in so far as it usually involves a transformation of awareness (cosmovision or the form of seeing the world). However, it does not necessarily produce a change in practice and can often lead to relativism. Therefore, self-reflection does not seem sufficient to overcome the gap between the interpretative focus and its practical and emancipating scope.

Under the hermeneutic focus, even though researchers might interpret and report, they are limited in transforming practice. Therefore J. Habermas's critical social science suggests offering individuals a means not only to become aware of how their objectives and purposes might have been distorted by the social, cultural and political conditioners, but also to transform the social reality in which they are involved (Habermas 1982 and 1997). In social sciences this is possible provided the subjects that form part of the situation or problem take part and collaborate in the research process. According to W. Carr \& S. Kemmis, a critical social science must be (Carr; Kemmis 1988):

"a social process that combines collaboration in criticism with the political will of acting to overcome the contradictions of the social action and social institutions regarding their rationality and justice”.

According to these principles of critical social science, by including the subjects of the problem in the research team itself, they experience their own awareness-raising process (self-reflection) that necessarily leads to a will to transform reality. At the same time the researcher, previously a spectator, also experiences a process of selfreflection on their own role as a researcher and their own trade by mixing their interpretations with those of the agents involved and by sharing the decision-taking with respect to methodologies and actions aimed at transformation, giving rise to a transforming will of the discipline itself.

In the field of design, which always has a practical orientation (a will to transform), in addition to the process of self-reflection on the part of the designer-researcher it would be a question of involving the subjects or users both in the process of investigating the problem and in developing its solution. In fact there are techniques already widely applied such as joint creation, discussion groups and feedback interviews during the processes of investigating and developing projects which are guided by this emancipating focus (Casacuberta, 2003; Jullier, 2010; Osterwalder; Pigneur 2010; Guersenzvaig, 2010).

However, this eminently creative and productive character specific to the design discipline adds a degree of complexity. Theoreticians such as A. Findelli defend creativity as a fundamental element both in the project and in research in the design field (Findeli 1999). Therefore, every research process in the field of design must not be limited by the epistemological premises of its focus, but must incorporate a transforming interest as practical knowledge. Design poses practical problems about what has to be done, therefore the solution lies in doing something.

Léchot Hirt (2010) quotes E. During in the sense that design research must be structured around methodological and operational elements in a heuristic process of balance between research and creation. By coining this term "research-creation", the suggestion is to pay attention to the produced object, to the "tangible" result of creativity in any phase of the research. The results of the researchcreation process must not be understood as proof or demonstration of the epistemological focus, but rather as possibilities that constantly transform the research field. Creativity and practice are therefore essential elements of the process on the same level as knowledge or research rigour.

Finally, we must understand that these types of processes do not reject other kinds of knowledge, but rather suggest integrating technical (positivist) knowledge and practical (interpretative) knowledge from an emancipating or transforming focus. At the same time, explaining a phenomenon (positivist approach) or understanding a phenomenon (interpretative approach) are but moments in the transformation process and not actual purposes of the science (Carr; Kemmis 1988).

In the next chapter, our experience shows the participation of the different focuses in different stages of an educational process focused on design as a means of transforming a problem.

\section{Research-action with Graphic Design Students and Residents of Barcelona's "Barri Gòtic"}


Having defined and explored the different theoretical perspectives in the design field, in order to confront different problems and realities we suggest reflecting on an educational experience that we had the chance to have as teachers during the 2010-11 academic year on the 3rd year of the ELISAVA design degree. Seeing the different situations that occurred throughout the experience, we proposed the application of the focus considered by critical social science. We therefore followed the postulates of W. Carr \& S. Kemmis (1988) and J. Elliot (1990) for education, in our case: the design field.

In this context, W. Carr \& S. Kemmis explain critical educational science as an action research process which consists of (Carr; Kemmis 1988, 168):

“/.../ a form of investigation carried out by those who participate in social situations to improve the rationality and justice of: a) their own education social practices; b) their understanding of them and; c) the situations and institutions in which these practices are carried out”.

This initial definition allows us to understand that, in our context, students and teachers must co-operate during the research process, which is aimed at developing new educational models in the design field, and students must include the collaboration and participation of the subjects involved in the problem they were facing in their research and design projects. Only in this way will we start the transformation process both of the educational model suggested by the teachers and the social problem dealt with by the students. This means that the educational processes must be processes of research into educational practice and processes of practice of the discipline at the same time. The teachers must play a double role as teachers and researchers, whereas the students must play a triple role as student, design professional and researcher.

We had the chance to start up this educational researchaction when a representative of the Asociación de Vecinos del Barri Gòtic de Barcelona (AVVBG), in the district where the design school is located, presented us with their proposal for collaborating on an educational project. We had a definite client. The member of the AVVBG suggested creating a group of graphic design students to make suggestions for the informative leaflet of the association and its corporate image. The tutors redefined the commission in the form of a suggestion for the AVVBG communication campaign so that the students would not be accepting a professional commission but would rather be dealing with a question that would give them broad pedagogical development. The AVVBG agreed and so we had a definite commission for the students. The school formed a team of volunteer students under the supervision of two teachers to develop a graphic design project for the residents' association. The students coming into the project were very excited and motivated as this was one of the first professional-type commissions led by the school.

In this stage, the traditional positivist focus procedure for commissions of this kind was applied. A meeting was held between students, teachers and a residents' representative to define the commission. After the meeting, the students were left free to try out all the technical skills and knowledge that they had acquired in their training. The tutors assigned to the project only made sporadic suggestions in order to maintain the quality of the project. In this phase, the tutors expected to work as intermediaries between the AVVBG and the students, trusting that the precision of the briefing and the students' capacity would ensure the conventional development of the project.

After a couple of weeks, the students already had a final proposal, so a presentation was organised for the AVVBG delegate at the school. The application of creative techniques and the use of new technologies brought forth a bold, groundbreaking proposal aimed at an aggressive, powerful communication to accompany the vindicative nature of the AVVBG, as we had been told by its representative.

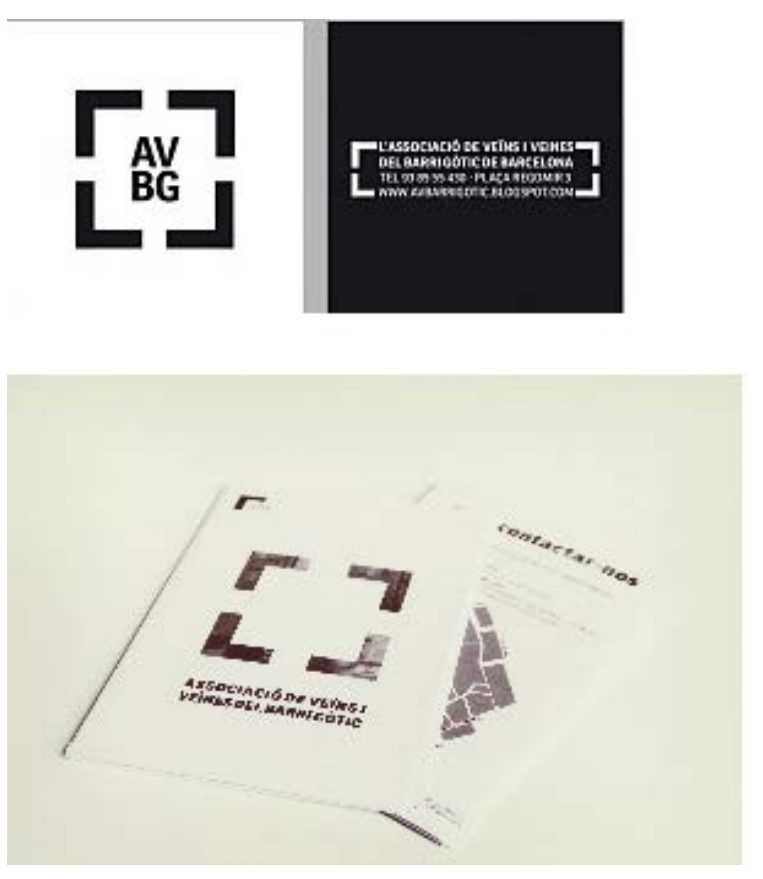

Figure 1. Logo and informative leaflet in student's first proposal. Source: Pol Trias; Dani Llugany

The representative was very impressed and grateful. Both the informative leaflet and the logo they had designed for the corporate identity upheld and modernised the association's image. However, when the delegate presented the results to the rest of the members of the association, there was strong criticism of the corporate image. It was generally argued that the design would give the association an excessively enterprising identity. They were not a company, but rather an association of residents. However, the representative argued in favour of the project and his opinion finally overrode with the support of one sector of the association.

The students then remained in contact with the AVVBG representative and worked on designing different issues of the informative leaflet. The meetings created a bond between the students most involved and the association's representative. At the same time, the students started the second term with a subject called Product, context and user, based on an anthropological-hermeneutic approach. The teachers of this subject called upon the students to make a guided study focused on the use of the qualitative research techniques typical of social science methods. One of the teachers' conditions was that the students should forget about researching to create or design prototypes and should only focus on trying to understand. Some of the students who were still in contact with the residents' association suggested to the teachers that they might research into the Gothic quarter and the association. The 
research started with four of the students who had taken part in the previous phase. The aim was to understand the district and its relationship with the residents' association in greater depth and with a hermeneutic focus. The questions made of the group of researchers were therefore:

- What are the meanings and functions of the Gothic quarter?

- What are the social problems in the Gothic quarter? Causes of the problems?

- What problems are put forward by the residents' associations? Causes of the problems?

- What relationship is there between the residents' associations and the territory?

The field work was carried out using some of the traditional qualitative techniques: documentary sources (literature on the district, magazines, press, documentaries, etc.), distant observation (prospecting), and participant observation, making use of the bonds that had been sown with the residents' association in the work done on the informative leaflet, and in-depth interviews. The fieldwork helped to strengthen the bonds with the already known members of the residents' association and relationships were also started with other associates and residents. The students became involved in some of the activities carried out by the Association: the district assemblies and the organic food co-operative.

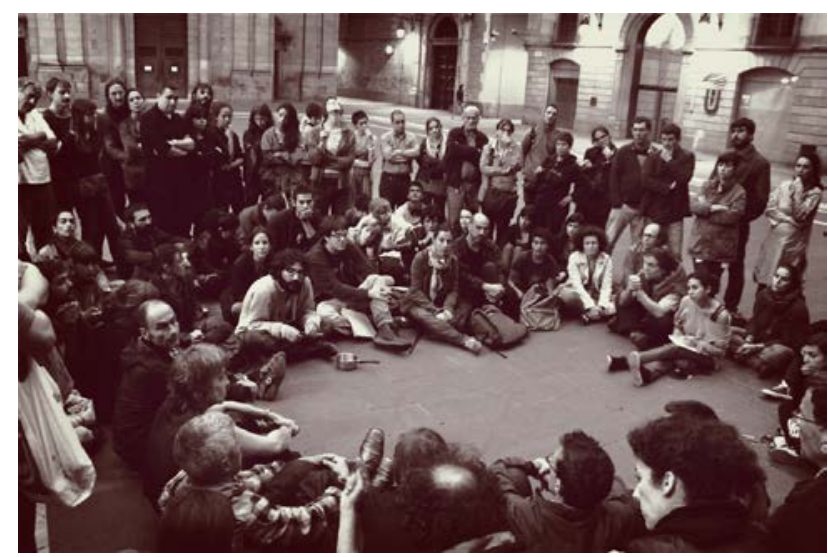

Figure 2. District's residents street assembly. Source: Pol Trias; Dani Llugany

The results of the research presented in a report and a series of interviews showed an interpretive understanding on the part of the students of the experience that they had had in their three months interacting with the district and the association. Amongst other conclusions, the students revealed that the district's history explained many of its problems today. In the early 20th century, a policy was started to turn the ancient cathedral district into the Gothic quarter in order to turn the area towards tourist activity. To do this, a number of architectural works were undertaken to simulate the inheritance of a mediaeval past (Cócola 2011). Today, the city’s governmental policy has enhanced and extended the district's tourist activity, largely thanks to the development of global tourism, the new information technologies and transport, but also thanks to the city's situation in the global economy. The cultural diversity of the present residents (many of whom are foreign) and the presence of mass tourism have broken the traditional relations in the district associated with a more culturally standard group of residents. The residents' association is suffering some consequences of this. It seems that the members of the association no longer represent its great diversity, although it was possible to distinguish two profiles of members, corresponding to two different generations. The residents' association had lost influence in the district and had fewer and fewer members. It seemed that the district's heterogeneity had made them invisible. However, they made a great effort to offer the residents services, activities and to give advice. They also organised to call for solutions to district's problems: the uncontrolled growth of tourist apartments and the rise in delinquency.

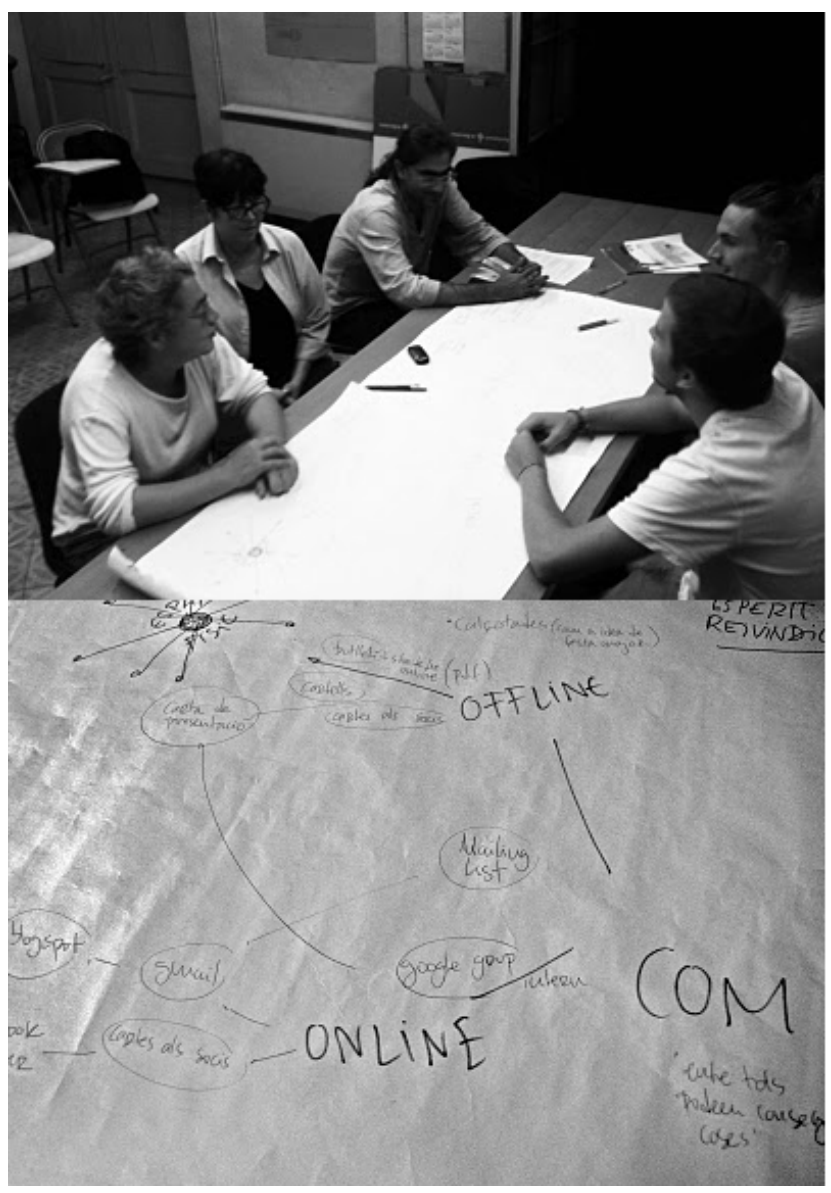

Figure 3. Briefing and mindmap previous to second proposal. Source: Pol Trias; Dani Llugany

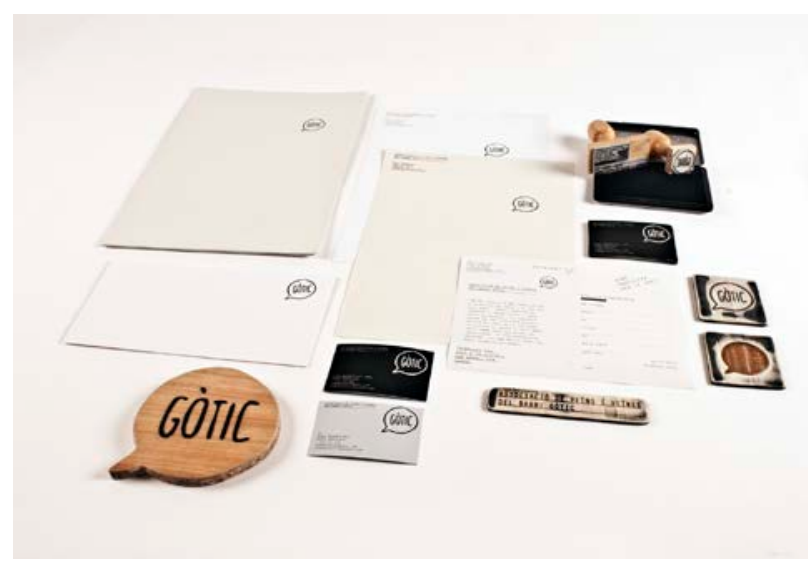

Figure 4. Corporate identity and stationery of students' second proposal, including low-tech applications. Source: Pol Trias; Dani Llugany

The efforts made in the research process made some of the students drop out. Furthermore, the presentation of the results of the research, long awaited by some of the 
members of the association, failed to come up to expectations. The members of the association who saw the results said they already knew and that no new conclusions had been drawn. However, the knowledge acquired by the students gave them a new focus to be able to propose a creation project to improve the one before.

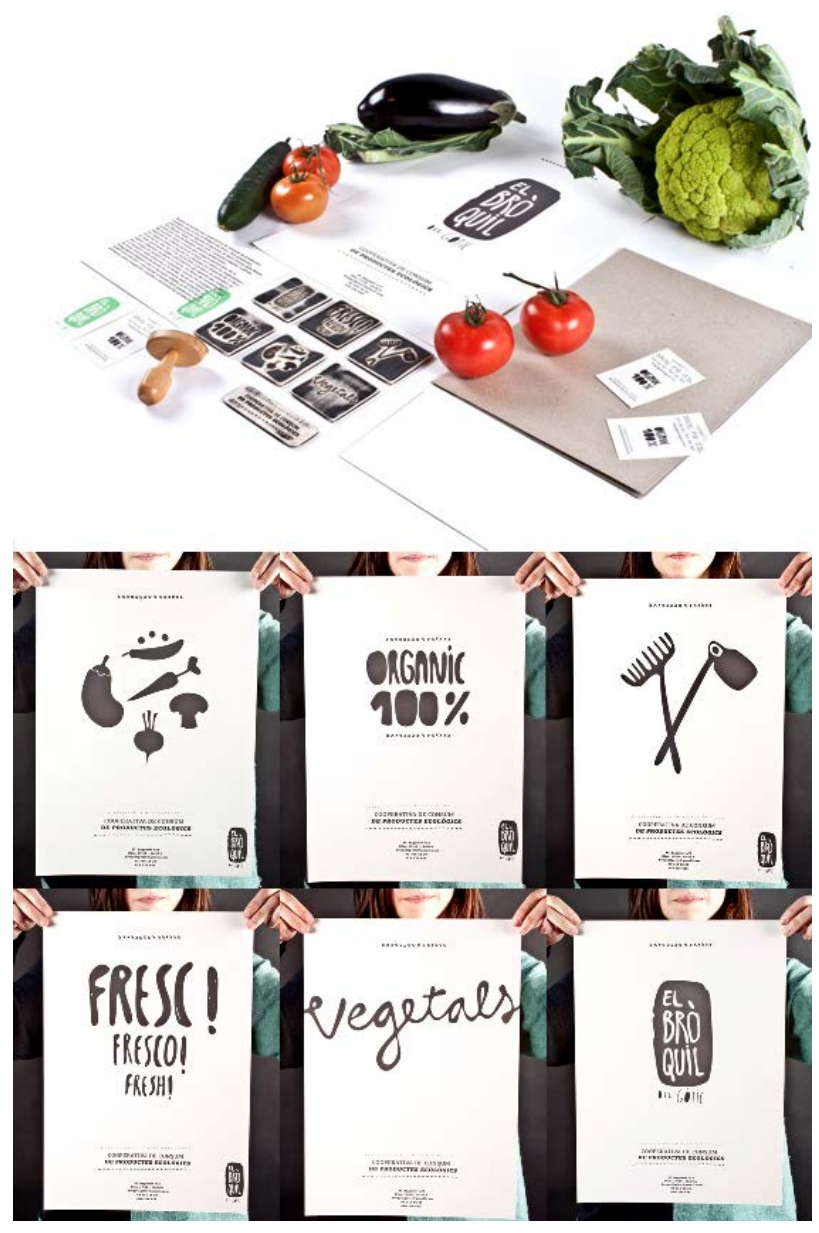

Figure 5. "El bròquil” food cooperative corporate identity. Source: Pol Trias; Dani Llugany

At this time, the school formed an interdisciplinary team of professors (communication, anthropology) to produce a workshop for students suggesting continuing with the experience. Therefore, in the second term, the members of the association and the group of students set out on a very intense collaboration and participation process. Meetings were held both at the school and in the association between residents, students and professors. The first meetings were used to discuss the commission, the proposals and the problems of the association. The typical tensions of perspectives, interpretations and experiences sometimes appeared at the meeting and some students and residents dropped out as a result. However, the goodwill of those most involved enabled the confusions and disagreements of a joint creation process to be overcome. Some design techniques applied as games with the residents, such as mindmaps or el brainstorming, helped to promote agreement and understanding. Then the students isolated themselves from the tutors and the AVVBG for weeks to leave a distance between them and develop creative processes that gave rise to new proposals. These were then discussed with the tutors and residents. Finally, the students worked independently again in order to adjust their proposals.
In the final results, the whole of the graphic campaign was developed in a warmer tone closer to the users of the AVVBG. The simplicity and visual clarity, as well as the warmth and relaxation in the formalisation, showed that the association was an inclusive, permeable place prepared to listen to the opinions of all of the district's residents. Furthermore, the proposal adapted to the means and resources of the association and enabled application in all kinds of formats, from the most conventional to the latest technologies. Signs, informative leaflets, corporate stationery, website and even a variant of the corporate image applicable to the district food cooperative were revealed.

The students also presented a campaign in which all of the claims and problems of the district were brought forth. The proposal was intended to cause awareness-raising in the district itself and reported the negative consequences of the policies that the local government was carrying out in the area. At the same time, the association was to be more visible and be given a new image of inclusion to bring in more members.

This reporting campaign was never carried out, although its presentation caused an internal debate of selfreflection in the association and regarding its relationship with the City Hall and the area.

In this last phase, the students' (Pol Trias and Dani Llugany) work, their capacity to understand the context and strike a balance between their creativity and their will to produce useful objects for the association was fundamental. It was their will to learn and understand which drove the traditional educational model towards the emancipated and critical focus. Far from being frightened of the complexity of the commission, which had caused moments of tension and disappointment among all of those involved, and far from being intransigent as designers, the students' work was an example of how to balance the capacities of any discipline with its adaptation to the context. The final presentation to the ELISAVA tutors and the members of the AVVBG was a perfect staging of the excellent results of the process. The final results that were presented to the association were widely accepted by the members and are still being used and transformed into new uses and functions.

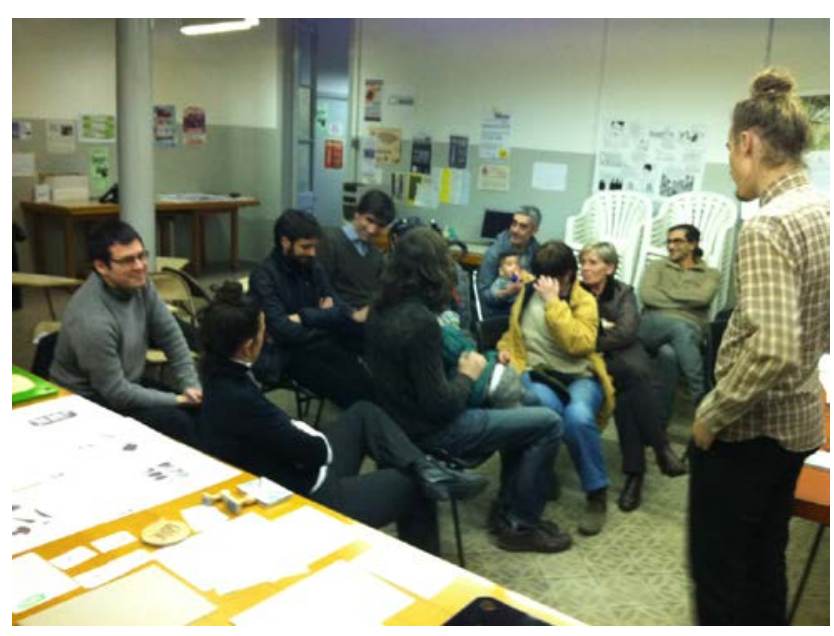

Figure 6. Final presentation, with all the participants (residents, students and teachers), in AVVBG's head office. Source: Pol Trias; Dani Llugany 


\section{Conclusions}

This case suggests that design as a discipline based on praxis incorporates its capacity to transform the surroundings in all processes. The concept of action research turned into creation research is almost intrinsic to design education. The described project shows how partial results become milestones of the process with a creative and formal power that force constant transformation in the model and the questioning of the initial premises. Both the students and the teachers, and particularly the users, reply actively and almost emotionally to these partial results that allow them to redefine their approach and, at the same time, to extend their field of knowledge. The creativity of the result becomes the true driving force of the emancipating learning process in all of the participants of the project.

A crisis is therefore revealed in the dominant positivist focus in design educational programs. If we understand design as a discipline aimed at solving practical problems, it is paradoxical that we insist on limiting its educational origin to technical (explanatory) knowledge or hermeneutic (interpretative) knowledge. If the solution to the problems posed by design lies in doing something, in the will to transform them, we will necessarily conclude that taking an emancipating approach in the educational processes seems to be far more coherent with their nature. As we have already mentioned in the conclusion of the second section, this does not mean that the emancipating focus rejects or ignores previous forms of knowledge, but rather suggests integrating them in the transformation process, just as this educational experience in the Barri Gòtic of Barcelona has shown.

However, there are two factors that cause problems in the process. On the one hand, we have already seen how this methodology causes a constant crisis in the process itself. Therefore, the agents involved (in our case the teaching staff, students, residents, the educational institution and the residents' association) were reformulated several times, causing changes in people, infrastructures and resources. The combination of these derivatives comes up against the rigidity of organisation and the University academic management. Furthermore, there is doubt as to whether the clarity with which the goodwill of this methodology in relation to the social aspects of design is seen in this case would be repeated in other areas, such as the scientific-technical or entrepreneurial.

Finally, we must stress the importance of these kinds of experiences for the relationship that the design school has and wishes to maintain with the area and its context. The practical theoretical focus deployed here promotes the institution's desire not to exist outside of what is happening in the district. The educational experience with the residents of the Gothic quarter shows the possibilities of ELISAVA's involvement, participation and influence in the transformation processes experienced by the social reality of the area where it is situated.
This all represents a challenge to further in the transformation and improvement of the educational models in the design field.

\section{Acknowledgement}

The authors wish to thank Virgínia Angulo, Noel Criado and Adrià Pujol from ELISAVA; the ELISAVA students Oriol Castellar, Dani Llugany, Hansel Schloupt and Pol Trias; and Teresa Muñoz, Reme and Albert Sancho from the AVVBG and others for their work and effort

\section{References}

[1] The critical theory was developed by philosophers from the Frankfurt School, such as T. Adorno, M. Horkeimer and $\mathrm{H}$. Marcuse, in the mid-20th-century, concern for the growing power of influence of the positivist focus of science as an ideology on 20th century Society. Later this was extended and consolidated by the approaches of critical social science made by J. Habermas in several works, such as Conocimiento e interés (1982), Teoría y praxis (1997), Teoría de la acción comunicativa (1987). Generally, critical theory, as W. Carr and S. Kemmis (1988: 146) say, tends to "express a focus of theory that proposes the central mission of emancipating people from the domination of positivist thought through their own understandings and acts”.

[2] W. Carr and S. Kemmis (1988) or J. Elliot (1990), amongst others, have taken critical social science to the field of education through the methodological focus they have called research-action. In general lines, this focus says that in order to produce emancipating or education-transforming knowledge, it is necessary not to separate research in the field of education from the educational praxis itself, and that it is essential to include the participation and collaboration of all agents involved in education (teachers, students, parents, institutions) in the research-action process. T. Eckes, The Developmental Social Psychology of Gender, Lawrence Erlbaum, 2000. [E-book] Available: netLibrary e-book.

[3] Carr, Wilfred; Kemmis, Stephen. Teoría crítica de la enseñanza. La investigación-acción en la formación del profesorado. Martínez Roca, Barcelona, 1988.

[4] Cócola, Agustín. El barrio Gótico de Barcelona. Planificación del pasado e imagen de marca. Generic Publishers, Barcelona, 2011.

[5] Casacuberta, David. Creación colectiva. Gedisa Publishers, Barcelona, 2003.

[6] Elliot, John. La investigación-acción en educación. Morata Publishers, Madrid, 1990.

[7] Findeli, Alain. “Introduction”, Design issues. 15 (2): 1-3, 1999.

[8] Guersenzavig, Ariel. "El disseny com a eina de transformació participativa”. Quaderns d'acció social i ciutadania. 8: 52-55, 2010.

[9] Habermas, Jurgen. Conocimiento e interés. Taurus Publishers, Madrid, 1982.

[10] Habermas, Jurgen. Teoría de la acción comunicativa. Taurus Publishers, Madrid, 1987.

[11] Habermas, Jurgen. Teoría y praxis. Estudios de filosofía social. Tecnos Publishers, Madrid, 1997.

[12] Julier, Guy. La cultura del diseño. Gustavo Gili Publishers, Barcelona, 2010.

[13] Lechot Hirt, Lysianne (dir.). Recherche-création en design. Metis Presses Publishers, Geneva, 2010.

[14] Margolin, Victor. "Design studies and the education of designers". Temes de disseny 6: 37-54, 1991.

[15] Osterwalder, Alexander; Pigneur, Yves. Business Model Generations. John Wiley\&Sons Publishers, Hoboken, 2010. 